\title{
THE BURDEN OF COVID-19 ON HEALTHCARE RESOURCES IN INDIA
}

\author{
Swagata Mandal \\ Biostatistics and Demography, International Institute for Population Sciences, Mumbai, India \\ Email: swagata9011@gmail.com
}

\begin{abstract}
The COVID-19 pandemic has caused huge pressure on healthcare systems all over the world. This prevailing infectious virus requires constant testing of cases, isolation of patients, treatment and research on vaccination, medication, transmission and prevention. This study aims to determine the burden the virus has made on the Indian healthcare systems. Testing and isolation of the cases is the mechanism being used to combat the pandemic so this study analyses the tests performed, testing labs for COVID-19 and hospital beds in the state level. Based on the importance of testing, the doubling time of the tests performed and the confirmed cases is calculated. Graphical analysis is undertaken to study the public hospital beds, testing labs, positive cases and tested cases state-wise. The results indicate that more tests need to be performed, and for this to occur more testing labs should be set-up and sufficient isolation beds must be constructed for the treatment of the patients.
\end{abstract}

Key words: COVID-19, Healthcare, Testing Labs, Tests, Health Care Resources

\section{Introduction}

The first case of COVID-19 occurred in Wuhan Seafood Market, China in December 2019. The virus was named as Severe Acute Respiratory Syndrome Coronavirus-2 (SARS-CoV-2) or novel coronavirus (Guan 2020). The symptoms observed were similar to pneumonia (GAO 2020). The initial symptoms reported were mainly fever, with a few cases of having difficulty in breathing, and chest radiographs showing invasive pneumonic infiltrates in both lungs (WHO 2020). After the first identification, this virus began spreading rapidly and the spreading mechanism was unknown to the specialists (Rothan 2020). It was then observed that there was a human-to-human transmission of this virus (Phelan 2020). On $30^{\text {th }}$ January 2020, the World Health Organisation declared COVID-19 as Public Health Emergency of International Concern after it had spread across several countries globally (Cascella 2020). On 11 ${ }^{\text {th }}$ March 2020, COVID-19 was declared as a pandemic by WHO. India was not able to escape the spread of the virus. On $6^{\text {th }}$ April 2020, the Union Health Ministry of India declared that it was in between stage 2 and 3 of the pandemic. India went under nationwide lockdown on $24^{\text {th }}$ March 2020, and is proposed to remain till $3^{\text {rd }}$ May 2020. To tackle the virus outbreak, testing is an important step (Sanchez 2020). The healthcare workers are working day and night to combat the disease and cure the patients. This study is dedicated to analysing the healthcare resources in India.

\section{Data Source}

The data on daily testing of COVID-19 cases are obtained from the Indian Council of Medical Research. ICMR updates their daily tests performed to detect the SARS-CoV-2 virus. The data is on daily testing for our analysis is taken till $19^{\text {th }}$ April 2020. The data on state-wise labs present for testing novel coronavirus is also taken from the report released by ICMR on their website. This data is taken till $20^{\text {th }}$ April 2020. The data on total COVID-19 state-wise affected cases are taken from the Ministry of Health and Family Welfare (MOHFW) website. Since the number of cases is 
increasing every moment, we take the data updated on the website till 5:00 pm on $20^{\text {th }}$ April 2020. The number of daily cases is also taken from the MOHFW website. The data on public hospital beds present in each state of India is also taken from the MOHFW press release. The list of public hospitals present was last updated in July 2018 by the ministry. Data on individual state testing is obtained from the health departments of the respective state.

\section{Confirmed Cases and Daily Testing of COVID-19}

The first case of novel coronavirus infection was found in Kerala, India on $30^{\text {th }}$ January 2020. The number of cases was constant for a long time and suddenly increased $2^{\text {nd }}$ March 2020 onwards. There were only three cases in India on $2^{\text {nd }}$ March 2020, but as on $20^{\text {th }}$ April, the number of cases went up to 18539 (Fig. 1). As of $12^{\text {th }}$ April 2020, there were 9205 positive cases of COVID-19, and we can see that the number has doubled in a short span of only eight days. Though it is alarming to see the steep rise in the number of cases, it is equally important to identify these cases at the earliest so that proper treatment measures can be taken.

Figure 01: Confirmed Cases of COVID-19 in India (2 ${ }^{\text {nd }}$ March 2020 to $20^{\text {th }}$ April 2020)

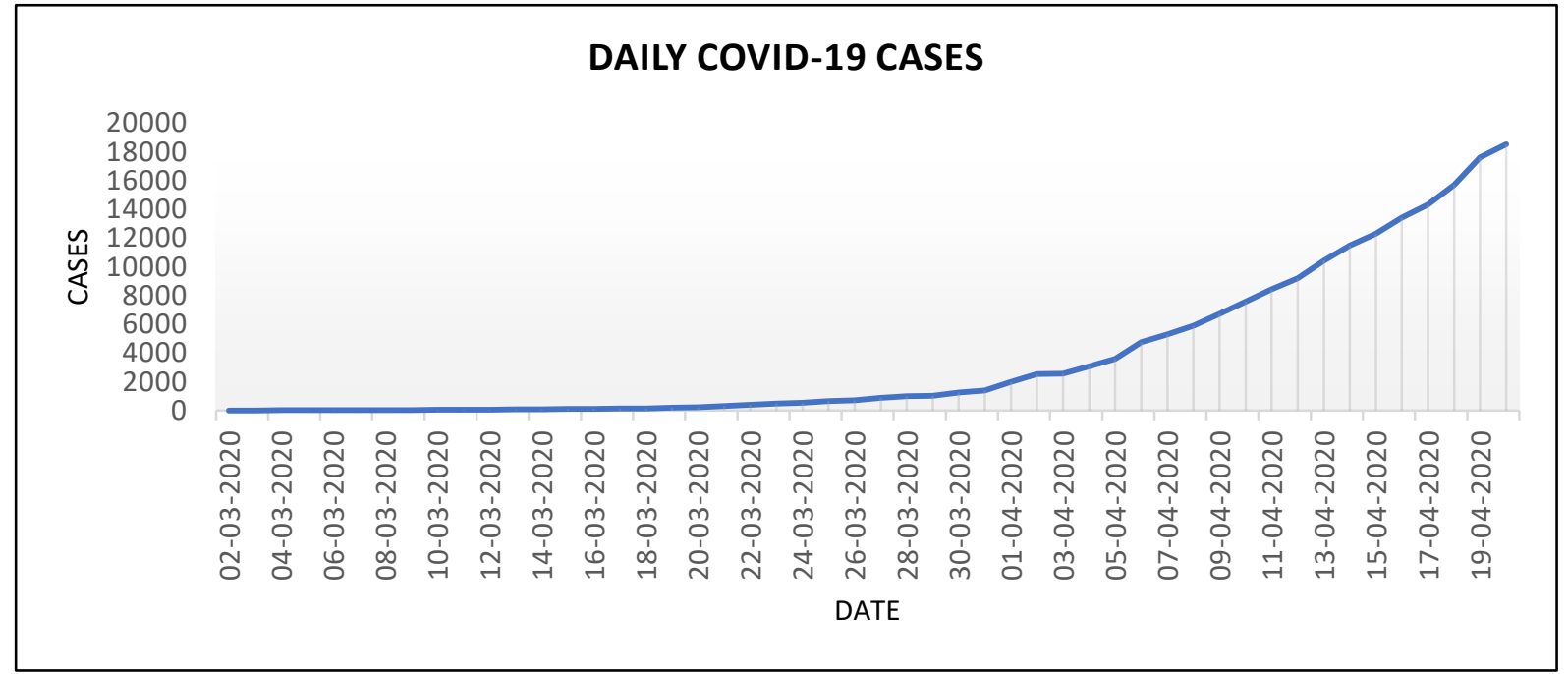

Figure 02: Daily Testing of Samples for COVID-19 (17 ${ }^{\text {th }}$ March 2020 to $19^{\text {th }}$ April 2020)

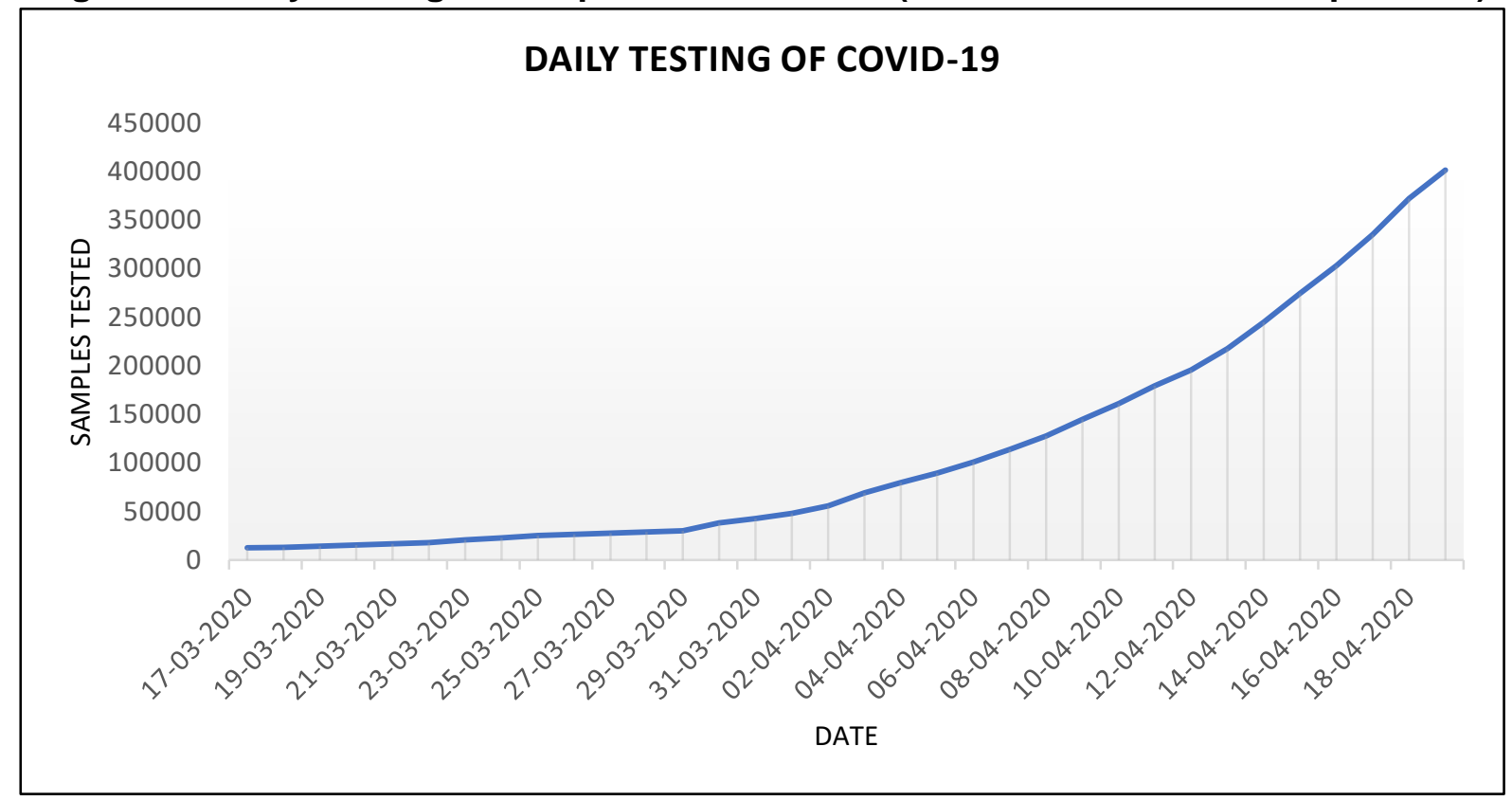


The testing of samples is very important to recognize the hidden cases of COVID-19. As of $19^{\text {th }}$ April 2020, there were 401,586 samples tested to find the novel coronavirus (Fig. 2). The number of samples tested on $12^{\text {th }}$ April 2020 was 195,748 and the number of samples tested has doubled only in seven days. We can see that the government of India has increased the number of testing to find out the undetected novel coronavirus cases. It is also observed from Fig.1 and Fig.2 that the number of confirmed cases has increased at the same rate as the number of tests performed. Thus, it becomes important to perform more tests to identify the cases faster and provide proper treatment to them.

\section{State-wise Healthcare}

The novel coronavirus infection has affected each state of India in different ways. Some states could not escape the consequences of the infectious virus while others are low in the charts. Fig 3 displays the fifteen states that have positive novel coronavirus infections greater than two hundred as on $20^{\text {th }}$ April 2020. Maharashtra is leading the charts with 4,203 cases. Maharashtra had more cases than Delhi and Gujarat combined. It is important to perform sufficient test to detect the COVID-19 cases.

Figure 03: States most affected by COVID-19 (as on $20^{\text {th }}$ April 2020)

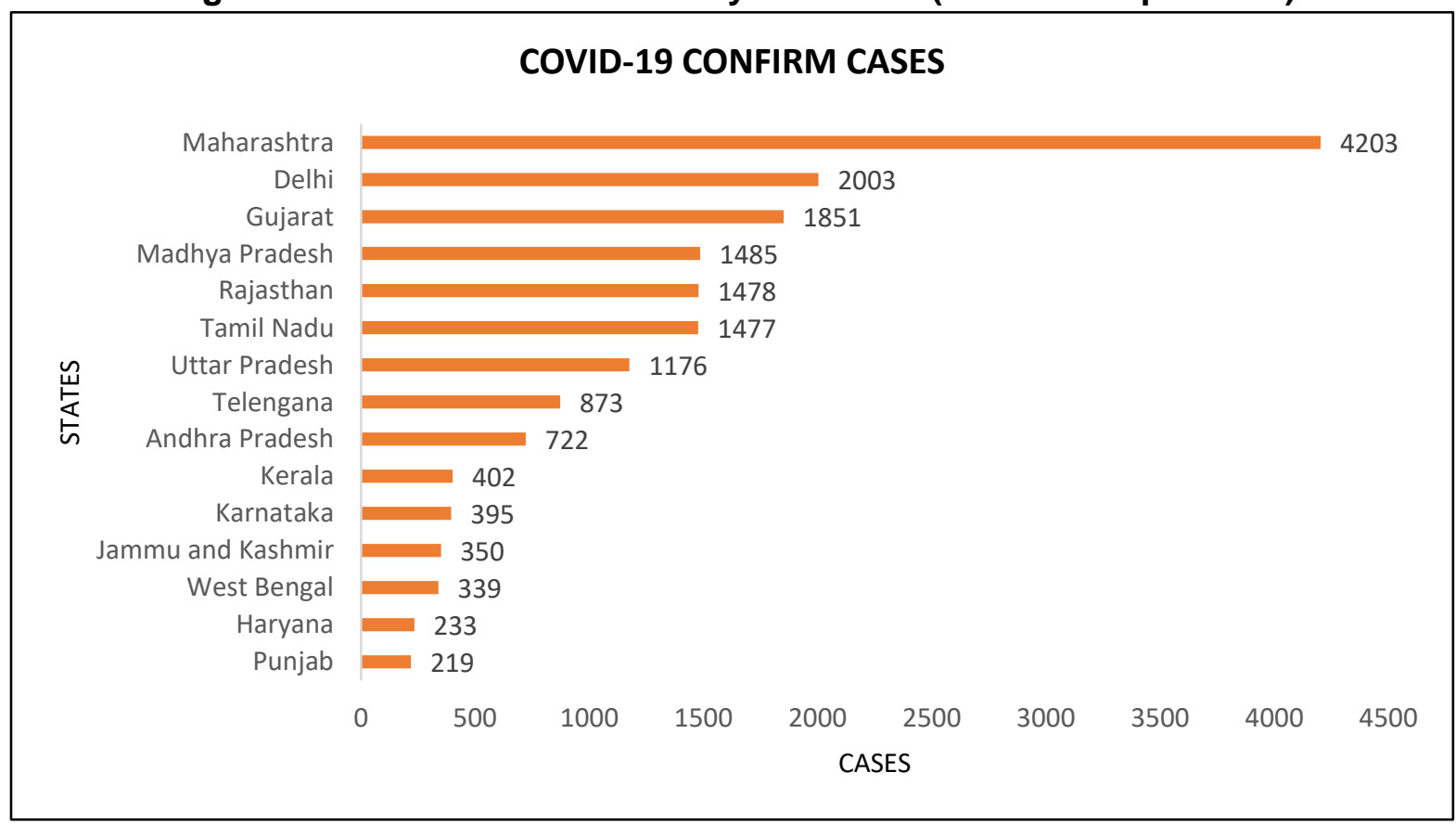

To facilitate abundant testing in each state of India, there must be a well-equipped lab facility to enable quality testing. Fig 4 contains the functioning testing centres in each state which are certified by the Indian Council of Medical Research. There are a total of 290 labs for testing COVID-19 all over India. We find that Maharashtra has the maximum number of testing labs in India with twenty-two government labs and twenty private labs. Tamil Nadu ranks second in the number of testing labs followed by Telangana. Also, there are about twenty-two states and union territories where the number of testing labs is less than ten. The government must take measures to increase the testing centres so that we can get the number of patients infected by the virus at the earliest. Table 1 presents the number of COVID-19 tests performed in the states as per the available information from the respective health departments as of $10^{\text {th }}$ April 2020 . We find that the maximum number of tests is performed in Maharashtra. The state of Rajasthan has performed fairly better in conducting COVID-19 tests despite a lower number of testing labs. The union territory Delhi must conduct more tests and construct more labs for testing since the number of 
confirmed cases is very high. We also observe that the number of positive cases tested in Tamil Nadu is higher than the comparing states. Odisha accounts for the lowest positive turnout of the tested cases. Testing of the cases is necessary and a greater number of labs and tests will ensure better identification of the cases. After the testing process, there must be an adequate number of beds available to accommodate the patients for treatment.

Figure 04: COVID-19 Testing Labs in States and UTs $\left(20^{\text {th }}\right.$ April 2020)

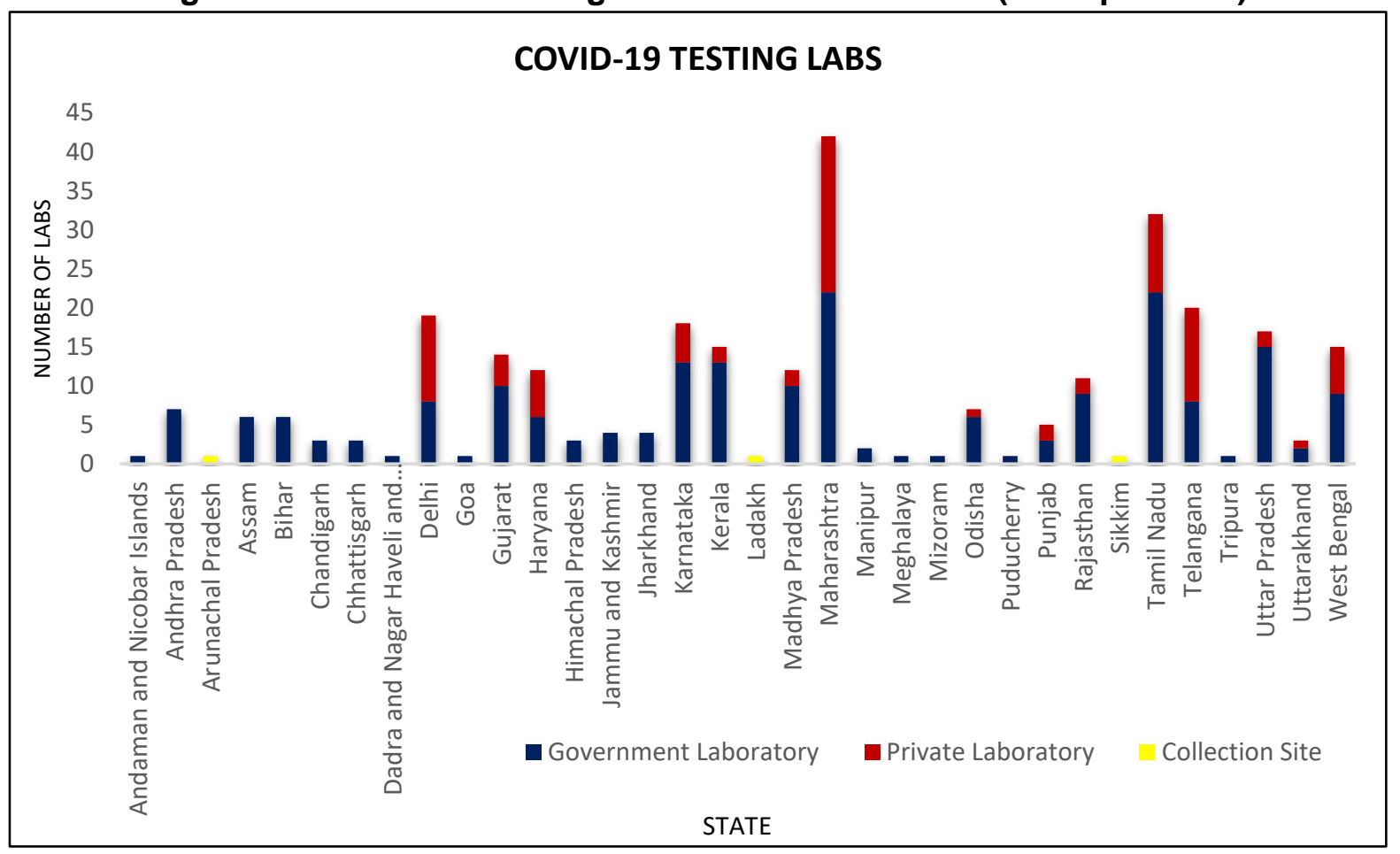

If we consider Table 1, which gives us the number of public beds available across India as of July 2018 , there are a total of 739,024 public beds are available in India. Tamil Nadu tops the charts with 72,616 public beds available. Maharashtra ranks second with 68,998 public beds. Comparing with the total number of cases in the states, we can be assured that we have a fairly large number of existing public beds alone so that the patients can be well accommodated. The government authorities of the Centre and States have also taken steps to dedicate many schools and other public institutions for COVID-19 care.

Table 01: Covid-19 Tests Performed in States/UT

\begin{tabular}{|r|l|r|r|r|}
\hline & STATE/UT & $\begin{array}{l}\text { Total tested } \\
\text { Samples }\end{array}$ & $\begin{array}{l}\text { Percentage of } \\
\text { Negative Cases }\end{array}$ & $\begin{array}{l}\text { Percentage of } \\
\text { Positive Cases }\end{array}$ \\
\hline 1 & Maharashtra & 30000 & 96.22 & 3.78 \\
\hline 2 & Rajasthan & 22324 & 92.60 & 2.33 \\
\hline 3 & Kerala & 13339 & 92.47 & 2.73 \\
\hline 4 & Delhi & 11061 & 87.35 & 8.16 \\
\hline 5 & Tamil Nadu & 8410 & 81.31 & 10.83 \\
\hline 6 & Karnataka & 7975 & 96.21 & 2.60 \\
\hline 7 & Gujarat & 7718 & 93.77 & 6.90 \\
\hline 8 & Madhya Pradesh & 7049 & 68.66 & 5.98 \\
\hline 9 & Andhra Pradesh & 6374 & 94.02 & 4.36 \\
\hline 10 & Punjab & 3461 & 85.87 & 1.48 \\
\hline 11 & Odisha & 3249 & 98.52 & 6.99 \\
\hline 12 & Jammu and Kashmir & 2961 & 93.01 & 8.52 \\
\hline 13 & Chandigarh & 223 & 89.24 & \\
\hline
\end{tabular}




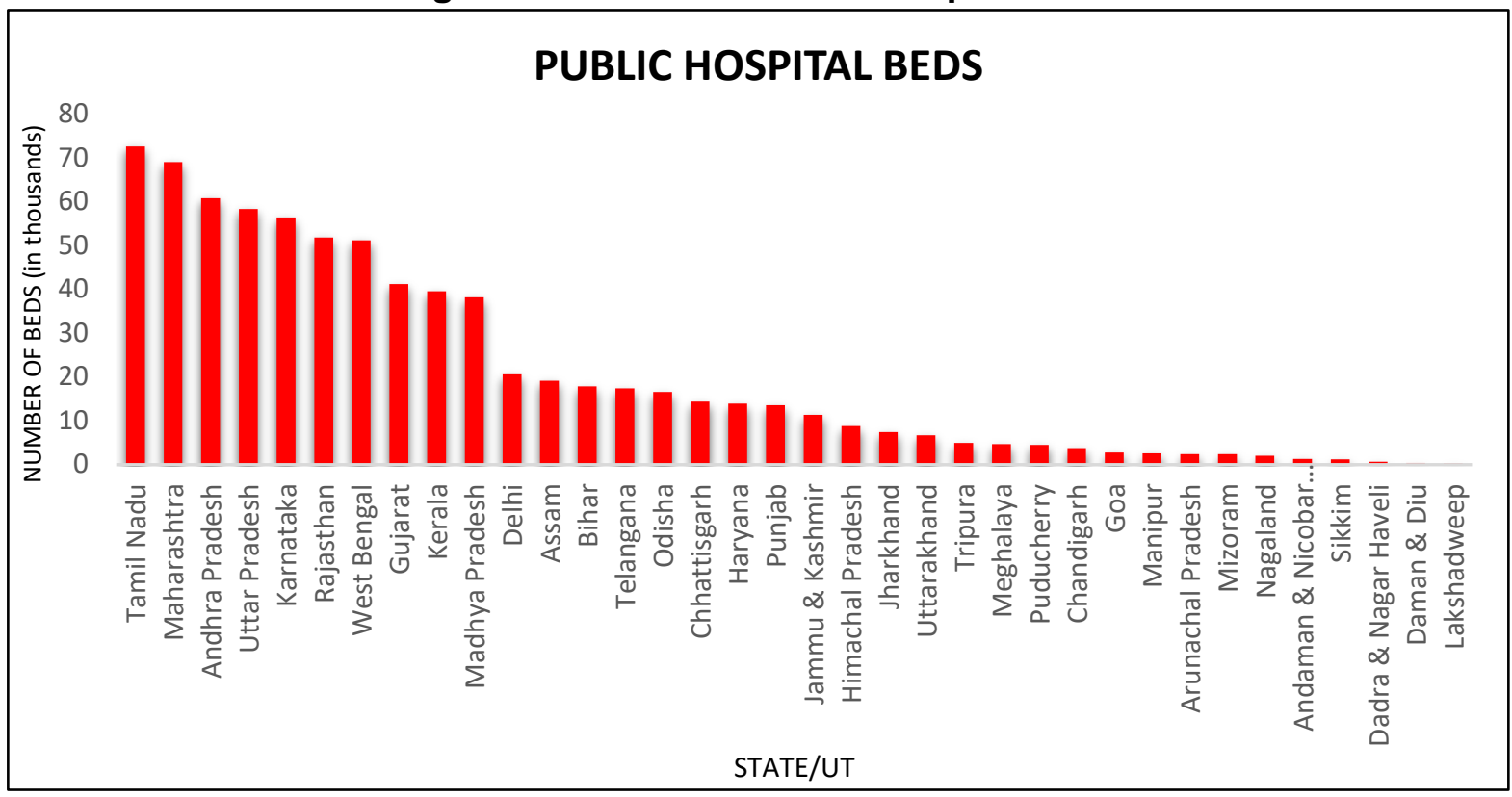

\section{Conclusion}

The number of confirmed cases in India has crossed seventeen thousand as of $21^{\text {st }}$ April 2020 . The testing for COVID-19 cases is also increasing. The government should construct more testing labs and employ more professionals to speed up the process. ICMR has imported rapid testing kits to perform faster testing of individuals. From the hospital beds, we see that India already has sufficient public beds. The beds for COVID-19 patients must be isolated from other patients so that infection transmission is prevented. The patients with any possible symptoms or possible exposure are put under quarantine till the test results are known. So, the government must make arrangements for such special quarantine centres in bulks as soon as possible. India is currently under lockdown till $3^{\text {rd }}$ May 2020, but the lockdown must be extended to a sufficient duration if the cases of COVID-19 are not in control.

\section{References}

1. Cascella, M., Rajnik, M., Cuomo, A., Dulebohn, S. C., \& Di Napoli, R. (2020). Features, evaluation and treatment coronavirus (COVID-19). In Stat Pearls [Internet]. Stat Pearls Publishing.

2. Guan, W. J., Ni, Z. Y., Hu, Y., Liang, W. H., Ou, C. Q., He, J. X., ... \& Du, B. (2020). Clinical characteristics of coronavirus disease 2019 in China. New England Journal of Medicine.

3. Guo, Y. R., Cao, Q. D., Hong, Z. S., Tan, Y. Y., Chen, S. D., Jin, H. J., ... \& Yan, Y. (2020). The origin, transmission and clinical therapies on coronavirus disease 2019 (COVID-19) outbreak-an update on the status. Military Medical Research, 7(1), 1-10.

4. Phelan, A. L., Katz, R., \& Gostin, L. O. (2020). The novel coronavirus originating in Wuhan, China: challenges for global health governance. Jama, 323(8), 709-710.

5. Rothan, H. A., \& Byrareddy, S. N. (2020). The epidemiology and pathogenesis of coronavirus disease (COVID-19) outbreak. Journal of autoimmunity, 102433.

6. Sanchez, E., (2020, April 2) COVID-19 Science: Why is testing so important. American Heart Association, Retrieved from https://www.heart.org/en/news/2020/04/02/covid-19science-why-testing-is-so-important

7. World Health Organization (January 12, 2020). Novel coronavirus - China. Jan 12, 2020. Retrieved from https://www.who.int/csr/don/12-january-2020-novel-coronavirus-china/en/ 